\title{
Field trip in the Nepal Himalayas
}

\author{
Francisco Gutiérrez ${ }^{1 *}$, Michael Crozier $^{2}$ \\ 'Department of Earth Sciences, Zaragoza University, Spain, *fgutier@unizar.es \\ ${ }^{2} \mathrm{School}$ of Geography, Environment and Earth Sciences, Victoria University of Wellington, New Zealand
}

\begin{abstract}
Short information about the geomorphological field trip in the Nepalese Himalayas. The field trip was conceived as a traverse across the entire High Himalayan system, travelling along the Kali Gandaki River up to the Thakkhola Graben, and passing between the Annapurna-Nilgiri Range and the Dhaulagiri. The field trip was largely focused of various aspects related to hazardous geomorphological processes associated with an extreme mountain environment: high local relief and rapid tectonic uplift, glaciated mountains, frequent large earthquakes, severe and contrasting monsoonal precipitation, and unregulated rivers.
\end{abstract}

Key words: Kali Gandaki River, Thakkhola Graben, Annapurna, Dhaulagiri, Nepal

After the 9th International Conference on Geomorphology in New Delhi (November 6-11, 2017), organised by the International Association of Geomorphologists and the Indian Institute of Geomorphologists, 28 geomorphologists from 12 nationalities (Austral- ia, Brazil, France, Germany, Israel, Italy, Nepal, New Zealand, Poland, Russia, Spain, United Kingdom) had the great pleasure to participate in a wonderful field trip B9 in Nepal: Geomorphology of the Nepal Himalayas: A transect across the Annapurna Range (No-

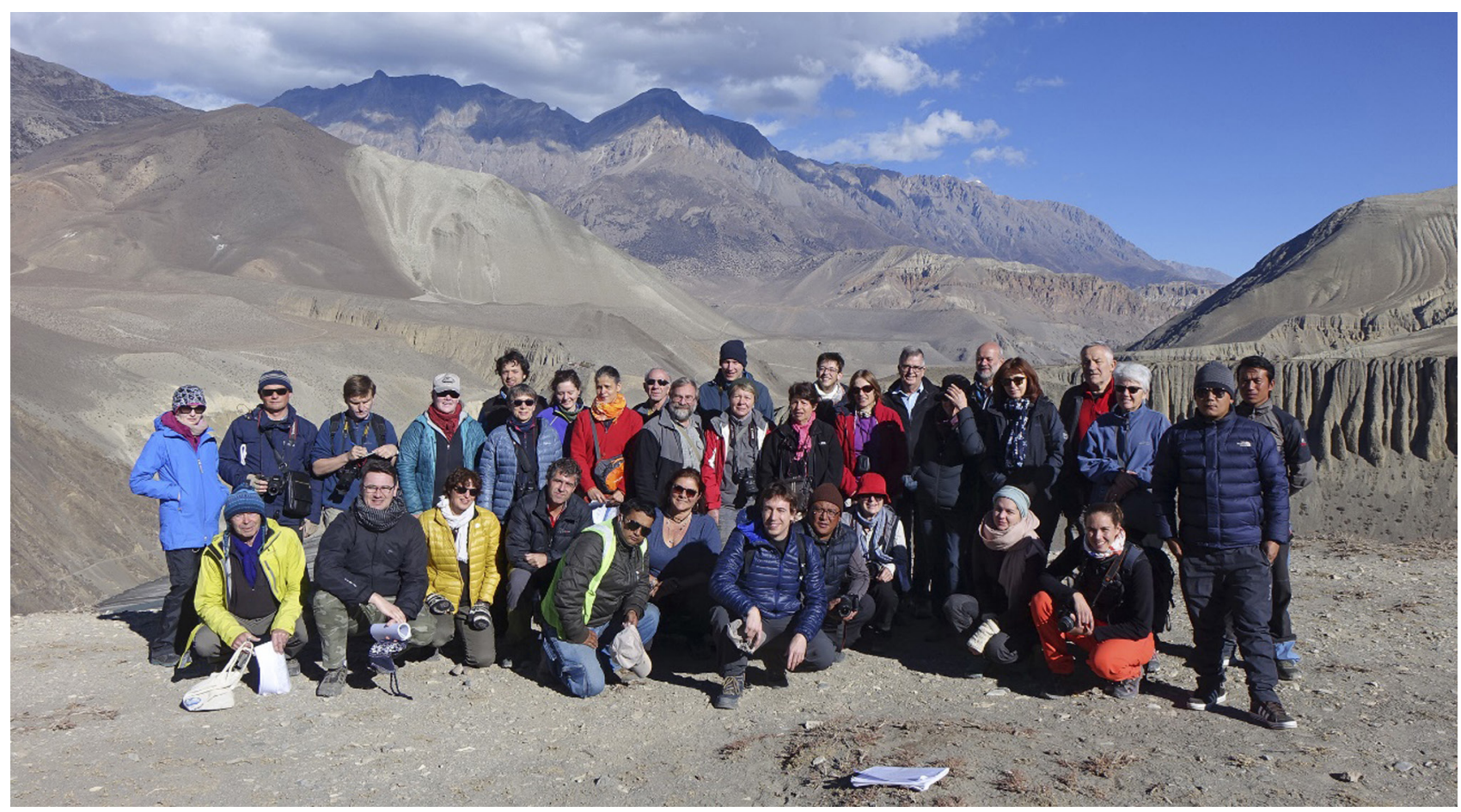

Fig. 1. Participants of the Nepal Himalayas field trip 


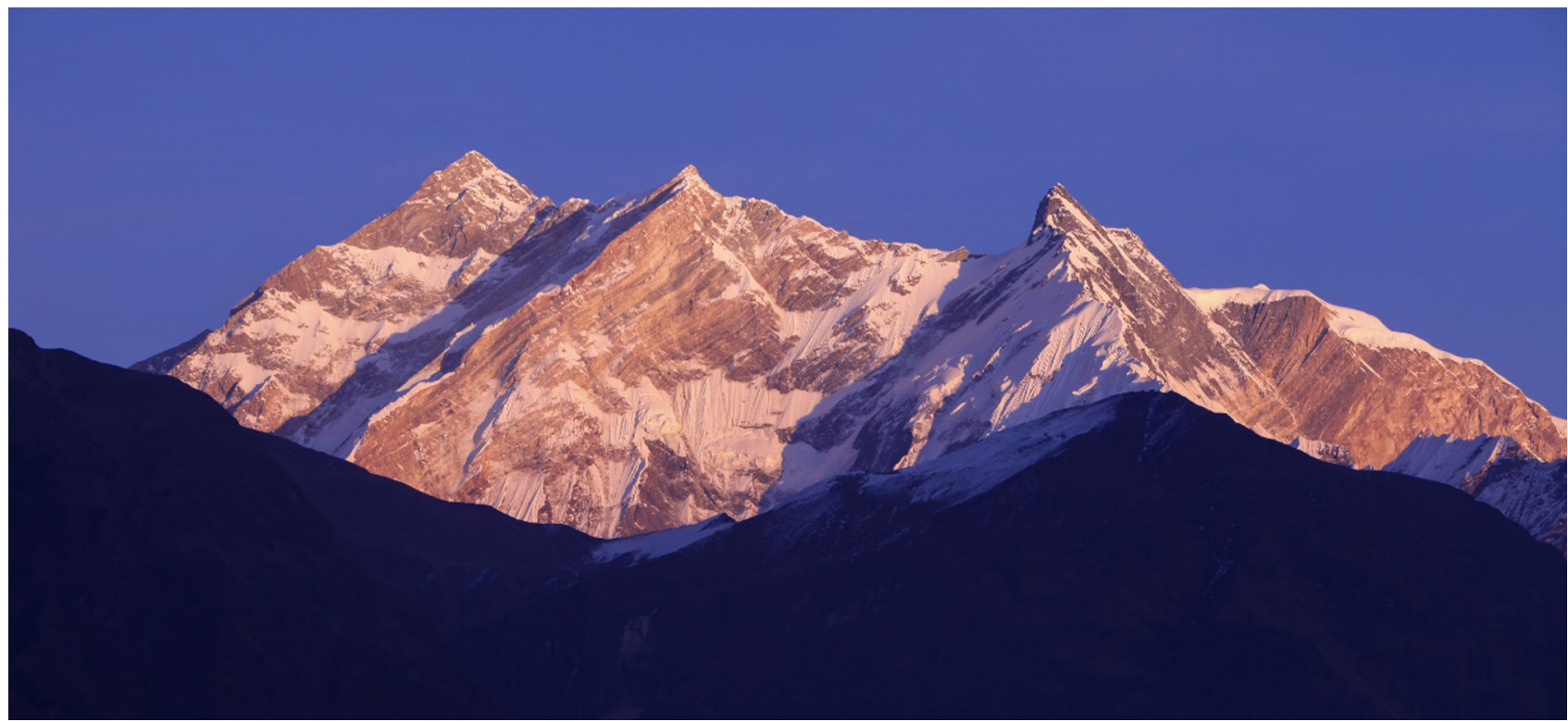

Fig. 2. The Annapurnas showing hogbacks developed on N-dipping strata

vember 12-19, 2017) (Fig. 1). The trip was magnificently organized and led by Prof. Monique Fort (Paris Diderot University, France), with the support of Dr. Basanta Raj Adhikari (Tribhuvan University, Nepal) and Prof. Narendra Raj Khanal (Tribhuvan University, Nepal). We also had the extremely kind assistance of the guide Babulal Lal Lama Tamang (Tribeni Trek, Nepal) and three helpers, as well as the skill of seven drivers that made possible the impossible.

Prof. Monique Fort started her investigations in Nepal in the 1970s, when the only way to get access to her study areas was by hiking with porters during

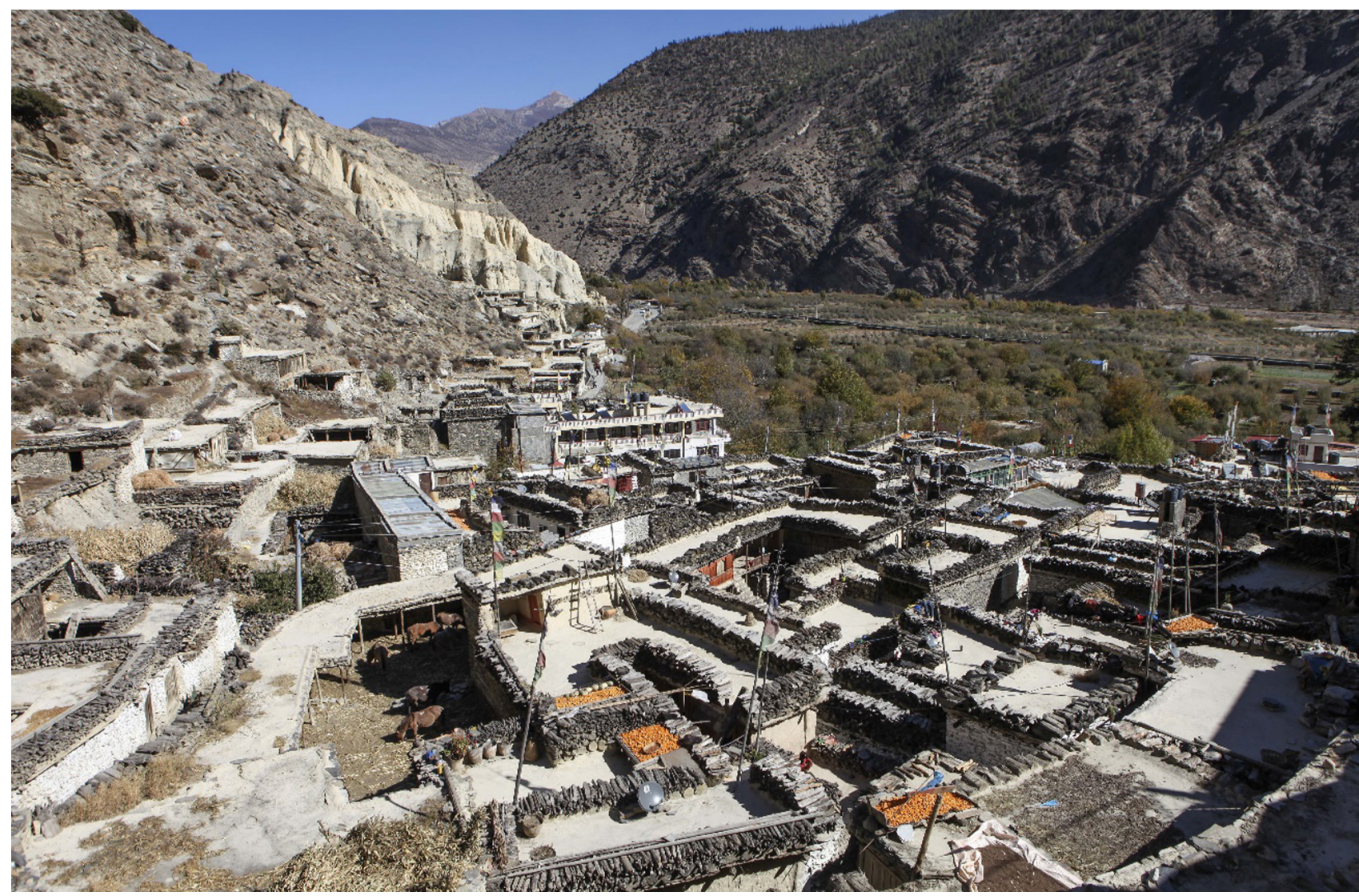

Fig. 3. Fine-grained sediments of the Marpha Lake at Marpha (behind the village), formed upstream of the natural dam created by the Dhampu-Choya rock avalanche 
weeks. She transmitted to participants of field trip, not only her profound knowledge on the geomorphology of the Nepal Himalayas, but also her devotion to the Nepali people for their kindness, hospitality and loyalty.

The field trip was conceived as a traverse across the entire High Himalayan system, travelling from Kathmandu to Pokhara and then along the Kali Gandaki River up to the Thakkhola Graben, and passing between the Annapurna-Nilgiri Range (8 $091 \mathrm{~m}$ a.s.l) and the Dhaulagiri (8 $167 \mathrm{~m}$ a.s.l); a dream for every geomorphologists. The field trip was largely focused of various aspects related to hazardous geomorphological processes associated with an extreme mountain environment:

- local reliefs higher than $4 \mathrm{~km}$ and rapid tectonic uplift;

- glaciated mountains with peaks above $8000 \mathrm{~m}$ a.s.l. (Fig. 2);

- frequent large earthquakes (e.g., $7.8 \mathrm{M}_{\mathrm{w}} 2015 \mathrm{Ne}$ pal earthquake);

- severe and contrasting monsoonal precipitation;

- unregulated rivers.

We traversed three major tectonic domains with distinctive geomorphological features, from south to north: Lesser Himalayan Zone, Higher Himalayan Zone and Tibetan Tethys Zone, bounded by the south-verging Main Central Thrust and the South Tibetan Detachment, respectively.

One of the main highlights of the field trip was the examination of giant pre-historic rock avalanches that created large landslide dams and long-standing lakes (e.g., Talbagar avalanche, Dhampu-Choya avalanche, Thini-Syang-Jomosom rock avalanche). These presumably earthquake-triggered catastrophic events, together with the drainage of the landslide-dam lakes, incorporated sharp changes in the longitudinal profile, sediment availability and behaviour of the fluvial systems. For instance, the Dhampu-Choya rock avalanche accumulated a pile $450 \mathrm{~m}$ thick of chaotic breccias in the valley floor damming the river and creating the $23 \mathrm{~km}$ long Marpha Lake, recorded by lacustrine sediments more than $200 \mathrm{~m}$ thick that penetrate into the tributary drainages (Fig. 3).

Participants of the field trip also had the chance to examine smaller historical rock avalanches that temporarily blocked major rivers and caused social and economic losses:

- the Baisari rock avalanche, triggered by the 2015 seismic series, which buried a small village, fortunately evacuated before the occurrence of the main slope failure; and

- the 1988 Tatopani rock avalanche, which caused flood damage at Tatopani village.

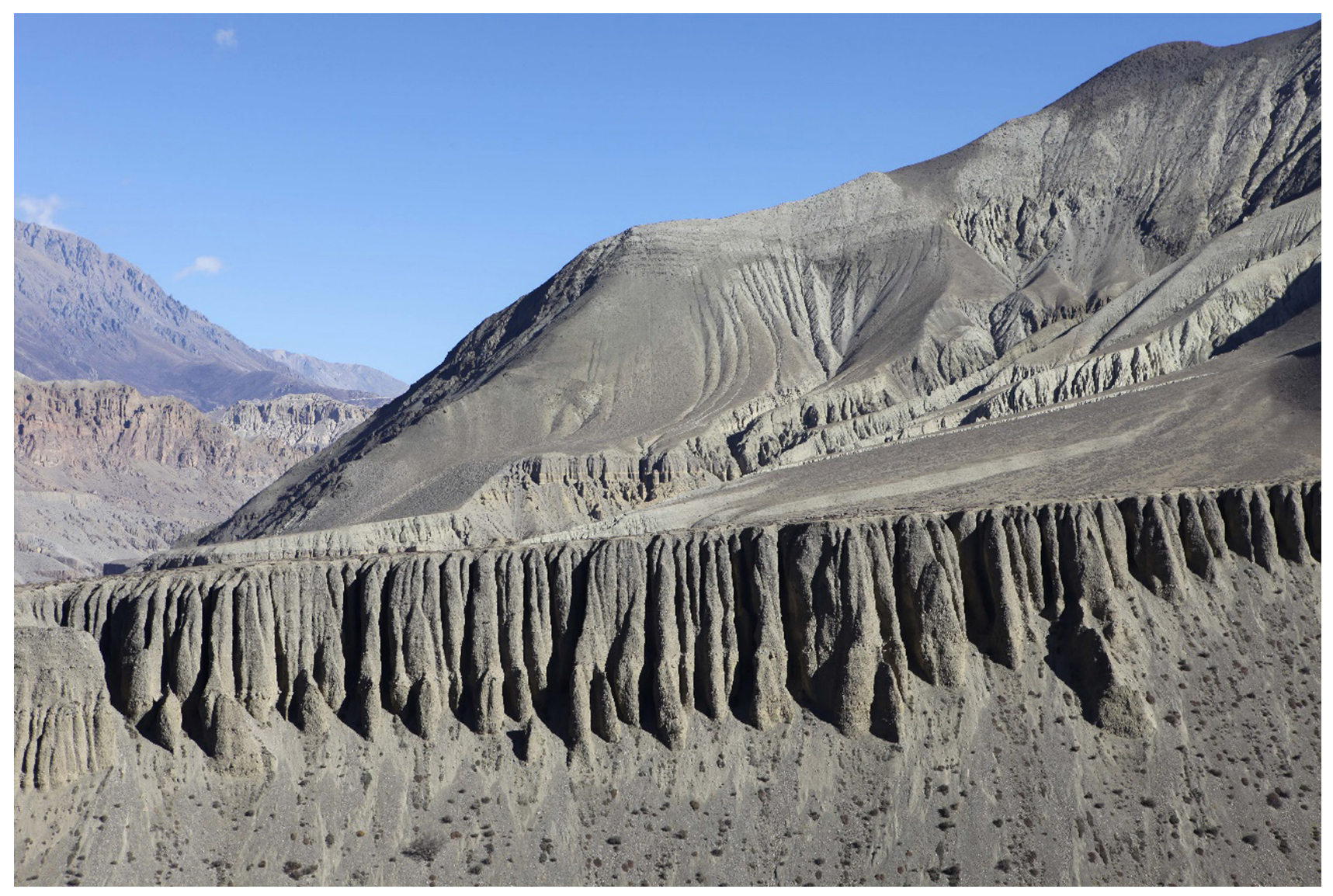

Fig. 4. Peculiar badlands developed on indurated gravel terrace deposits in Kagbeni area 
Landslides in the steep mountain catchments may also induce debris flows by rapidly incorporating sediment to the torrents (e.g., Beg Khola), or flash floods by the burst of short-lasting landslide dams. For instance, the 5 May 2012 Seti River flood, which caused 32 known fatalities and 40 missing persons in Kharapani hotsprings area.

The program of the field trip included other interesting geomorphic features such as terraces underlain by floatbreccias more than $100 \mathrm{~m}$ thick (Kali Gandaki River at Kusma), water falls from hanging tributary valleys, the Thakkhola Mio-Pliocene Half-graben related to recent extension in the Tibetan Plateau, cave dwellings and impressive badlands in indurated terrace deposits (Kagbeni area) (Fig. 4), a large active earthflow at Khingar, horns (Macchapuchare Peak or Fish Tail) and perched glaciers, sequences of thick fill terraces (Seti Khola Riiver), a fracture-controlled cave developed in cemented calcareous Quaternary alluvium and a swallow hole (Gupteshwor Cave and Davi's Fall, Pokhara), knick points associated with a sharp change from broad alluvial rivers to incised bedrock channels with impressive potholes and flutes (Seti Kola River at Dhulegaunda).

At the end of the field trip there was a common "mantra": we want to come back!

\section{Selected references}

Adhikari, B.R., Wagreich, M., 2011. Provenance evolution of collapse graben fill in the Himalaya - the Miocene to Quaternary Thakkhola-Mustang Graben (Nepal). Sedimentary Geology 233 (1-4): 1-14. DOI: 10.1016/j.sedgeo.2010.09.021.

Bhandary N.P., Yatabe R., Dahal R.K., Hasegawa S., Inagaki H., 2013. Areal distribution of large-scale landslides along highway corridors in central Nepal. Georisk: Assessment and Management of Risk for Engineered Systems and Geohazards 7(1): 1-20. DOI: 10.1080/17499518.2012.743377.

Bricker J.D., Schwanghart W., Adhikari B.R., Moriguchi S., Roeber V., Giri S., 2017. Performance of Models for Flash Flood Warning and Hazard Assessment: The 2015 Kali Gandaki Landslide Dam Breach in Nepal. Mountain Research and Development 37(1): 5-15. DOI: 10.1659/MRD-JOURNAL-D-16-00043.1.

Carosi R., Gemignani L., Godin L., Iaccarino S., Larson K. P., Montomoli C., Rai S. M., 2014. A geological journey through the deepest gorge on Earth: The Kali Gandaki valley section, west-central Nepal. Journal of the Virtual Explorer, Electonic Edition 47 Paper 7, In: Ch.Montomoli, R.Carosi, R.Law, S.Singh, S.M.Rai (eds.), Geological field trips in the Himalaya, Karakoram and Tibet. DOI: 10.3809/Jvirtex.vol.2014.052.

Dhital M.R., 2015. Geology of the Nepal Himalaya. Regional Perspective of the Classic Collided Orogen. Regional Geology Reviews. Springer. DOI: 10.1007/978-3-319-02496-7.

Fort M, Freytet P., Colchen M., 1982. Structural and sedimentological evolution of the Thakkhola-Mustang Graben (Nepal Himalaya). Zeitschrift für Geomorphologie N.F., Suppl.-Bd. 42: 75-98.
Fort M., 1987. Sporadic morphogenesis in a continental subduction setting: an example from the Annapurna Range, Nepal Himalaya. Zeitschrift für Geomorphologie N.F. Suppl.-Bd. 63: 9-36.

Fort M., 2010. The Pokhara Valley: a Product of a Natural Catastrophe. In: P.Migon (ed.), Geomorphological Landscapes of the World, Springer Verlag: 265-274. DOI: 10.1007/978-90481-3055-9 27.

Fort M., 2011. Two large late Quaternary rock slope failures and their geomorphic significance, Annapurna Himalayas (Nepal). Supplementi di Geografia Fisica e Dinamica Quaternaria 34(1): 5-16.

Fort M., 2015. Natural hazards versus climate change and their potential impacts in the dry, northern Himalayas: focus on the upper Kali Gandaki (Mustang District, Nepal). Environmental Earth Sciences 73(2): 801-814. DOI: 10.1007/s12665-0143087-y.

Fort M., 2017. B9: Geomorphological Field Guide Book on Nepal Himalaya. Indian Institute of Geomorphologists, Allahabad: $1-109$.

Fort M., Cossart E., Arnaud-Fassetta G., 2010. Hillslope-channel coupling in the Nepal Himalayas and threat to man-made structures: The middle Kali Gandaki valley. Geomorphology 124(34): 178-199. DOI: 10.1016/j.geomorph.2010.09.010.

Girault F., Bollinger L., Bhattarai M., Koirala B.P., France-Lanord C., Rajaure S., Gaillardet J., Fort M., Sapkota S.N., Perrier F., 2014. Large-scale organization of carbon dioxide discharge in the Nepal Himalayas. Geophysical Research Letters 41(18): 6358-6366. DOI: 10.1002/2014GL060873.

Hurtado Jr. J.M., Hodges K.V., Whipple K.X., 2001. Neotectonics of the Thakkhola graben and implications for recent activity on the South Tibetan fault system in the central Nepal Himalaya. Geological Society of America Bulletin 113(2): 222-240. DOI 10.1130/0016-7606(2001)113<0222:NOTTGA>2.0.CO;2.

Kargel J.S., Leonard G., Paudel L., Regmi D., Fort M., Mool P., Poudel K., Thapa B., Watanabe T., 2014. The 2012 Seti River flood disaster and alpine cryospheric hazards facing Pokhara, Nepal. Geophysical Research Abstracts 16, 12448-1.

Parsons A.J., Law R.D., Searle M.P., Phillips R.J., Lloyd G.E., 2016. Geology of the Dhaulagiri-Annapurna-Manaslu Himalaya, Western Region, Nepal. 1:200,000. Journal of Maps 12(1): 100-110. DOI: 10.1080/17445647.2014.984784.

Rai S.M., Upreti B.N., Yoshida M., Bhattarai T.N., Ulak P.D., Dahal R.K., Dhakal S., Gajurel A.P., Koirala M.P., 2005. Geology of the Lesser and Higher Himalayan zones along the Kaligandaki Valley, central-west Nepal Himalaya. Proceeding of the JICA Regional Seminar on National Disaster Mitigation, Kathmandu, Nepal: 43-56.

Schwanghart W., Bernhardt A., Stolle A., Hoelzmann Ph., Adhikari B.R., Andermann C., Tofelde S., Merchel S., Rugel G., Fort M., Korup O., 2015. Repeated catastrophic valley infill following medieval earthquakes in the Nepal Himalaya. Science 351(6269): 147-150. DOI: 10.1126/science.aac9865.

Stolle A., Bernhardt A., Schwanghart W., Hoelzmann Ph., Adhikari B.R., Fort M., Korup O., 2017. Catastrophic valley fills record large Himalayan earthquakes, Pokhara, Nepal. Quaternary Science Reviews 177: 88-103. DOI: 10.1016/j.quascirev.2017.10.015.

Upreti B.N., Yoshida M., 2005. Geology and natural hazards along the Kaligandaki Valley, Nepal. Guide book for Himalayan trekkers. Ser. 1, Dept. of Geology, Tribhuwan University, Kathmandu, Nepal: 1-165.

Zech R., Zech M., Kubik P.W., Kharki K., Zech W., 2009. Deglaciation and landscape history around Annapurna, Nepal, based on ${ }^{10} \mathrm{Be}$ surface exposure dating. Quaternary Science Reviews 28(11-12): 1106-1118. DOI: 10.1016/j.quascirev.2008.11.013. 